\title{
MODELLING FACTORS AFFECTING RELIGIOUS TOURISM FLOWS TO SAUDI ARABIA
}

\author{
Eman Alanzi ${ }^{1}$, Nada Kulen ${ }^{2} \&$ Thu-Huong Nguyen ${ }^{3}$ \\ 1,2,3Victoria University, Australia \\ (eman.alanzi@live.vu.edu.au, Nada.Kulen@vu.edu.au, Thu-huong.nguyen@vu.edu.au)
}

\begin{abstract}
Religious tourism demand is one of the major contributors to Saudi Arabia economy and considered to play an important role in the "Vision 2030", which seeks to diversify Saudi Arabia's economy reliance on oil revenues. As the country has undergone structural changes in international tourism and removed travel restrictions in the past few years, there is a need to identify the determinant factors that influence international tourists to plan and manage their trips. Therefore, this current study aims to investigate the effects of economic and noneconomic factors on international tourist flows by using A panel data gravity model for the period 2000-2019. The empirical evidence is based on the Generalized Method of Moments (GMM) and the Panel Regression technique. The findings of the regression show that the traditional gravity variables are important to explain Saudi Arabia's religious tourism demand. The study also has found that habit persistence, the Pandemic Index, GDP per capita of Saudi and the original countries, human rights and investments in the tourist sector have a significant and positive impact on religious tourism demand. While political risks, transport costs, and tourism price have a statistically significant and negative effect on religious tourists' arrivals. This study will contribute largely to the tourism demand literature by introducing country characteristics factors which include human rights issues as security proxies, pandemics, and quality of life and by measuring the impact of these variables in tourism demand in the context of an oil-based economy that under the transition to a diversified economy with a new vision. The findings of this study may assist in the development of Saudi Arabia's tourism sector and economic development by providing knowledge to policymakers, investors, and other tourism stakeholders.
\end{abstract}

KEYWORDS: Religious tourism demand, gravity model, economic factors, country characteristic factors, safety and security

\section{PURPOSE AND BACKGROUND}

The Vision 2030 project aims to increase the number of international religious tourists to 30 million by 2030. It would mean doubling the number of religious tourism visas, and thus the demand. Given the significance of religious tourism's recent contributions and its future potential for job creation and foreign exchange earnings, it is critical to investigate and identify the major determinants of international religious tourism in Saudi Arabia. Thus, this study investigates the role of economic and non-economic factors in affecting the demand for religious tourism.

\section{METHODOLOGY}

This study used an augmented gravity panel data model to determine inbound tourism and estimate their importance in explanation tourist arrivals to Saudi Arabia. For panel data, Gravity models are typically static, with no inclusion of lagged variables (Morley et al., 2014). 
Therefore, this study uses the Generalized Method of Moments (GMM) dynamic panel Data Analysis, Fixed Effect Method (FE) and GLS estimators. The distinguishing feature of the GMM method is that it is a dynamic method. It considers the effect of time on the efficiency of the function, while the FE method Time static method.

\section{FINDINGS}

The regression results of this study indicate that there are many independent variables that have a significant and positive impact on religious tourism demand such as word of mouth. GDP per capita original countries and Saudi Arabia pandemics index, human rights and investment in the tourism sector political risk, transport costs, and tourism price have a statistically significant and negative effect on tourism arrivals.

\section{CONCLUSION}

Due to the potential rise of the number of incoming religious visitors as part of Saudi Arabia's Vision 2030, it is worth investigating the determinants that influence international religious tourists' arrival to Saudi Arabia to foster a greater understanding of how the country can grow their tourism sector. The study mainly used the generalized moments model (GMM), random-effects method (RE) and the fixed effects (FE) method and an augmented gravity model has been employed.

\section{CONTRIBUTION/PRACTICAL IMPLICATIONS}

The contribution of this research is to develop a holistic static and dynamic model of economic and noneconomic factors (country characteristics) on religious tourism demand by using gravity model panel data. The findings of this study can contribute to the tourism and economic advancement of Saudi Arabia and facilitate information for professionals, tourism promoters and investors, economic operators and policymakers, to develop effective policies and strategies for religious tourism and achieve the goal of Vision 2030 to diversify the Saudi economy through the increase in the number of international visitors.

\section{REFERENCES}

Morley, C., Rosselló, J., \& Santana-Gallego, M. (2014). Gravity models for tourism demand: Theory and use. Annals of Tourism Research, 48, 1-10.

Rozina, S. (2019). Nexus between religious journeys and economic influences - The case of Saudi Arabia. International Journal of Religious Tourism and Pilgrimage, 7(3), 27-37. https://arrow.dit.ie/cgi/ viewcontent.cgi?article $=1243 \&$ context=ijrtp

Viljoen, A., Saayman, A., \& Saayman, M. (2019). Determinants influencing inbound arrivals to Africa. Tourism Economics, 25(6), 856-883. 